\title{
Effect of Principal Leadership Style Women's and Cultural Organization of Work Ethos Teachers
}

\author{
Bintara (masbintara19@gmail.com) \\ Widyamike Gede Mulawarman (Coresponden Authors) \\ FKIP Mulawarman (widyatmike64 @ gmail.com / widyatmike @ fkip.unmul.ac.id) \\ Azainil \\ FKIP Universitas Mulawarman (azainil@fkip.unmul.ac.id)
}

Received: 04 March 2021; Revised: 26 April 2021; Accepted: 28 July 2021

DOI: http://dx.doi.org/10.37905/aksara.7.3.1045-1062.2021

\begin{abstract}
:
This study aims to determine the effect of the leadership style of female principals and organizational culture on the work ethic of junior high school teachers in Samarinda. This research is a quantitative study using a correlational method. The total population was 126 teachers and the research sample was 96 teachers consisting of three different schools, namely SMPN 5, 10 and 38 Samarinda. The data collection technique uses a questionnaire that has been tested for validity and reliability. The data analysis technique used descriptive and inferential statistics, with simple linear regression, multiple regression, and correlation analysis. The results showed that the leadership style of female school principals $\left(\mathrm{X}_{1}\right)$ had a significant effect on $79.4 \%$. This shows that the better the leadership style of the female school principal, the better the work ethic of the teacher will be. It is also known that organizational learning $\left(\mathrm{X}_{2}\right)$ has a significant effect of $39.4 \%$. This shows that the better the school organizational culture, the better the work ethic of the teacher will be. Simultaneously the competence of school principals $\left(X_{1}\right)$ and organizational culture (X2) has a significant effect on teacher work ethics (Y) by $81.8 \%$. This indicates that the better the leadership style of female principals and organizational learning, the more teachers work ethic will be good.
\end{abstract}

Keywords: Female Principal Leadership Style, Organization Culture, The Work Ethic

\section{INTRODUCTION}

The success of a school in carrying out a quality education process is often identified with the success of the principal in managing all available resources. One of the indicators for the success of the principal is measured by the quality of education in the school he leads. In the context of education, the definition of quality includes the input, process, and output of education (Depdiknas, 2001). The principal is the key driving force for school development and progress and is responsible for increasing accountability for the success of students and their programs. In order for this to be achieved properly, the leadership of the principal needs to be empowered, so that the principal is able to play a role in accordance with his duties, powers and responsibilities (Purwanti, K., Murniati, 2014). The principal must be good at leading groups and delegating tasks and authorities. Human resources are very important assets for an 
organization. The success of an organization is largely determined by the quality of its human resources, because the achievement of each organizational goal is influenced by the behavior of the organization itself. The success of the organization is supported by the performance of employees or the work achieved by employees in carrying out tasks in accordance with the responsibilities assigned to them. According to (Purwanto, 2009) the profession as a teacher (teaching) is not just working for a living. Teaching and educating are professions that require special skills and talents or great interests. The interest and feelings of love for the teaching profession must be continuously encouraged and developed. Work ethic is a reflection of the enthusiasm and joy of a person after he / she has done a certain work in earnest which is reflected in the form of pride because the work is as expected, as well as giving feedbackpositiveto him. For a teacher, it is carrying out their duties, namely teaching. This means that in the work ethic there is seriousness in working, there is pleasure in doing and there is feedback (feedback) which is certainly beneficial for a teacher. In its implementation, a teacher's work ethic will be seen from their performance or performance in carrying out their duties. The extent to which a sense of responsibility, sacrifice and dedication in educating and teaching will describe the work ethic of a teacher. According to the opinion (Darodjat\&Achmad, 2015) that someone who has a high work ethic has the following characters: (1) Has a future orientation; (2) Hard work and respect for time; (3) Responsible; (4) Economical and simple; (5) perseverance and tenacity; and (6) Competing honestly and fairly.

Work ethic is defined as "morale which is the special characteristic and belief of a certain person or community group" Big Indonesian Dictionary (Alwi et al., 2008). Meanwhile, according to (Santoso\&Jalu, 2012), work ethic is defined as a person's attitude, personality, character, morals, behavior and ethics at work. Meanwhile, Sinamo (2008: 26) formulates that a professional work ethic is a set of positive behaviors rooted in thick awareness, fundamental beliefs, accompanied by total commitment to an integral work paradigm. (Tasmara, 2002) emphasizes that work ethic is the totality of personality, as well as how to express, view, believe and give meaning to something that encourages him to act and work optimally. (Sinamo, 2008) defines a work ethic as a set of positive work behaviors, which are rooted in awareness, fundamental beliefs, and total commitment to an integral work paradigm. The term paradigm in this concept means the main concept of work itself, which includes the underlying idealism, governing principles, the values that drive, the attitudes that are born, the standards to be achieved, including the main character, basic thoughts, code of ethics, moral code., and a code of conduct. Agree with (Mulyadi, 2008) that work ethic is the soul and spirit of work which is influenced by the way of looking at work. This perspective is rooted in the values that a society grows, develops and embraces. In line with (Tebba, 2003) says that work ethic is the spirit and mental attitude of a person or group of people as long as there is moral pressure. Ethos is also the foundation, ideas, minds, thoughts that will determine the system of action. This is because work ethic determines an individual's assessment of a job, it will determine the results to be achieved both quantitatively and in view of the results that are characteristic of a person. In other words, ethos is strongly influenced by the views or values held or recognized by an individual or a group.

Referring to a research conducted by (Bogler, 2001) entitled "The Influence of Leadership Style on Teacher Job Satisfaction", teachers' perceptions greatly affect teacher job satisfaction. The informal leadership of school principals affects teacher satisfaction 
both directly and indirectly through teachers' job perceptions. The results of this study indicate that the principal's leadership greatly determines the enthusiasm and satisfaction of teachers at work.

The role of a leader is concerned with making policies that are acceptable to all parties. If subordinates and leaders have the same vision and mission, it is very easy to trigger motivation to work better, so as to create a conducive organizational climate (Suryo, 2010). According to Wiles in (Burhanuddin, 1994) "leadership is all forms of assistance that can be given by someone for setting and achieving group goals. According to J. Canon in (Syaiful, 2009), leadership is the ability of a superior to influence the behavior of subordinates and the behavior of groups in the organization.

According to (Purwanto, 2009). Leadership is the ability of a person to influence others so that people who are influenced by him are willing and able to carry out the tasks assigned to him voluntarily, full of enthusiasm, there is joy in the bayin, and he does not feel forced. Meanwhile, according to (Armstrong \& Baron, 2005) in (Hartani, 2011), leadership is the process of inspiring all employees to work their best to achieve the expected results. In Ordway Tead (Kartini, 2005), stated that leadership is an activity to influence people so that the people they lead are willing to work together to achieve goals to achieve the desired goals. Meanwhile, according to (Tohidi\& Jabbari, 2012), "Leadership is setting a new direction or vision for a group that they follow, for example: a leader is the spearhead for that new direction."

... The leadership's includes the attention to common goals. The leaders is direct their energies to the individuals who are trying to achieve something together. The attention to common goals is gave the leadership an ethical additional tone, because it emphasizes the need for leaders to work with the followers to achieve a specific goal. Northouse (2013: 6) in (Andriani et al., 2018)

Based on some of the definitions or descriptions above, it can be concluded that leadership is a person's ability to influence other people, either individually or in groups. As well as the ability to direct the behavior of individuals or groups to have special abilities or expertise in the fields desired by the group, so that subordinates are happy to carry out the assigned tasks to achieve predetermined goals. The leadership style contains the meaning as a manifestation of the behavior of a leader, which concerns the ability to lead his subordinates. The embodiment usually forms a certain pattern or shape. This definition of leadership style is in accordance with the opinions of several experts, including according to (Nurkolis, 2006), leadership style is a pattern of behavior that is preferred by a leader in the process of directing and influencing workers. In addition, according to (Veithzal, 2002), leadership is a comprehensive pattern of a leader's actions, both visible and invisible to his subordinates. Meanwhile, according to (Hadari, 2006), it defines that leadership style is a pattern of behavior shown by a person when he tries to influence others.

The leadership of female school principals in education management in general turns out to be able to realize effective leadership because women have advantages in playing and creating organizational effectiveness, such as manifesting school achievements, creating kinship relationships and being able to empower members and 
also emphasizing organizational structure by emphasizing teamwork, trust, flexibility and willingness to share information (Halilah, 2011)

The results of research conducted by Mukh et al and McCrea \&Ehrich (Surya, 2010), state that the peculiarities of female school principal leadership consist of sensitive leading, people resourcing, and active managing.

...Gender differences in leadership can be accounted for through a variety of rationale. From interpersonal relationships to social role expectations to differences in perception and styles, men and women may indeed lead differently in addition to being 'followed' differently. Most assuredly, general agreement exists that men and women will naturally vary in their leadership styles. (Burn \& Martin, 2010)

The opinion of Burns \& Martin can be interpreted that gender differences in leadership can be accounted for through various rational thoughts. From interpersonal relationships to social role expectations to differences in perceptions and styles, men and women can indeed lead to different things. To be sure, there is general agreement that men and women will naturally exchange their leadership styles. (Bush \& Coleman, 2000) stated that in a study that identified some leadership differences between men and women as follows, $(a)$. that men were more concerned with finance and salaries than women, who were more concerned with people within the school and their own workload; (b). the striking competitiveness of the male. In contrast the women were more concerned with cooperation and sharing, and in teamwork; (c). men tend to be completely satisfied with their work, women more hesitant; $(d)$. men wanted status and recognition, whilst women do not seem to want to be a subject of status envy

Bush \& Coleman's statement can be interpreted as follows, (a). Men are more concerned with matters related to finances and salaries than women who are more concerned with people in school and their workload; (b). men strive in competitive terms, on the other hand women are more concerned with cooperation and sharing, and work in teams; (c). men tend to be easily satisfied with their jobs, while women are still doubtful; (d). Men want status and respect, while women do not seem to wantstatus to women's leadershipprioritize human relations, care for subordinates, pay attention to cooperation between members, respect and respect each other. Female leadership tends to communicate informally with subordinates and is more polite, uses collaborative strategies in resolving conflicts, is open and prefers to share with subordinates, likes to work in teamwork. More role as a motivator for the development of subordinates. The character of estri or woman in his leadership raises the character of being patient, polite, beating without violence and being good at diplomacy. Understanding of organizational culture is actually inseparable from the basic concept of culture itself, which is one of the terms that is widely used in the field of anthropology. Nowadays, from the perspective of anthropology itself, the concept of culture has experienced a shift in meaning. In the past, people argued that culture included all manifestations of virtuous and spiritual human life, such as: religion, art, philosophy, science, state administration and so on, religion, art, philosophy, science, state administration and so on. Today culture is defined as the manifestation of the life of each person and every group of people. Now culture is seen as something more dynamic, not something rigid and static. Culture is not interpreted as 
a noun. Now it is more interpreted as a verb that is related to human activities. Keith Davis and John, W. Newstrom 1989 in (Mangkunegara, 2005) argued that: "organization culture is the set of assumptions, believe, values, and norms that is shared among its members"

While Gordon Allport 1964 in (Muliyana, 2004) define value is a belief that makes a person act on his choice. Meanwhile, William J Bennett in (Benninga, 1991) states that:

"the Term value may suggest judgments of right, or wrong, Noble and Base, Just and unjust are Mere personal preferences, that things are whortwhile only if and insofar individuals to value them."

Organizational culture is characterized by sharing or the same values and beliefs with all members of the organization. For example, sharing the same values and beliefs through uniform. However, accepting and wearing a uniform is not enough. Wearing uniforms should bring pride to be a tool of control and shape the image of the organization. Thus, the value of uniform is embedded into the basics.

Then Wax (1993) in (Hoffman, 1996) proposes the concept of culture, namely: "Arguably, culture lies at the heart of multiculturalism. Yet, while the very concept of culture is under attack in anthropology, argument about culture in the school curriculum, for instance, occurs largely, in ignorance of or indifference to, this conceptual critique ...

By understanding the basic concepts of culture in general above, Furthermore, we will understand culture in an organizational context or what is commonly called an organizational culture (organizational culture). The definition of organization here is directed more in terms of formal organization. In a sense, the cooperation that exists between members has elements of vision and mission, resources, a clear legal basis for structure and anatomy in order to achieve certain goals. This definition includes what is important in life and can vary widely in different organizations. In some ways people really care about innovation or employee welfare. It is at this level that culture is very difficult to change partly because group members are often unaware of the many values that bind them together. At a visible level, culture describes the behavior patterns or styles of an organization so that new employees are automatically motivated to follow the behavior of their peers. (Robbins, nd) argues that organizational culture is a system of shared meaning held by members that distinguishes the organization from other organizations. This opinion is in line with the boundaries of organizational culture put forward by (Mondy et al., 2005) which states that organizational culture is "The system of shared values, beliefs, and habits.within an organization that interacts with theformal structure to produce behaviornorms."(A system of sharing values, beliefs, and habits within an organization in accordance with a formal structure to produce norms of behavior). In addition, (Luthans, 2006) defines organizational culture as a pattern of assumptions that are discovered and developed by groups thatcovers adaptation issues with partiesoutside and the integration that has been running withgood enough and reliable to be taughtto new members as an ordinancebehave, think and behave towardsthat problem. Robbins suggestsopinion that organizational cultureis a philosophy, ideology, values,presumptions, beliefs, expectations, attitudes andshared normsand binding in a communitycertain (Respect, 2016). In another part, Kotter and Heskett (1992) in (Molan, 2006) also explain three concepts of organizational culture, namely: (1) strong 
culture (2) strategically suitable culture, (3) civilized culture. Organizations that have a strong culture are marked by the tendency for almost all managers to share a set of values and methods of running the organization's business. New employees adopt these values very quickly, a new executive can be corrected by his subordinates, as well as by his boss, if he violates organizational norms. Each organization has an organizational culture that serves to form rules and guidelines for thinking and acting in achieving goals. set. This means that an organizational culture that grows and is well maintained will be able to spur the organization towards better development. The main pressure in changing and developing organizational culture is trying to change the values, attitudes and behavior of the members of the organization as a whole (Prihayanto, Susandi. \&Ratnawati, 2011). In organizations with a strong culture employees tend to line up following the same values. Common values and behaviors make people feel comfortable at work. A sense of commitment and loyalty makes people try even harder. In a strong culture provides the structure and control needed. rather than stifling formal bureaucracies that can suppress growing motivation and innovation. Organizational culture is pervasive in organizational life and subsequently affects every life of the organization. Therefore, organizational culture has a very big influence on the fundamental aspects of organizational performance. These aspects are the basis for monitoring employee behavior, the way they think, cooperate and interact with employees. To be able to manage it properly, it needs a clear understanding and attention to organizational culture. Organizational culture is believed to be the main determining factor for the success of organizational performance. If the organizational culture goes well, it will be able to improve employee performance (Gultom, 2014).

\section{METHOD}

type of research in this scientific paper uses a quantative approach, namely research by collecting data empirically, then processing it using statistics to determine the problem of whether or not the three variables studied are present. The method used is the correlational method, which is a study that is intended to determine whether there is a relationship between two or more variables. This study will use regression analysis techniques. Regression analysis technique or forecasting is an analysis technique used to predict or predict the dependent variable $(\mathrm{Y})$ if the independent variable $(\mathrm{X})$ is known (Riduawan, 2009). The study was conducted at SMP Samarinda, led by the female principal. The population is the total number of teachers. Of the 3 schoolsselected, randomly namely 126 people, using theformulaSlovin obtained a number of samples that were reached by 96 people. Collecting data using a questionnaire technique (questionnaire).

Data analysis used descriptive analysis and inferential analysis. Descriptive analysis aims to transform raw data into a form that is easy to understand, in the form of more concise information (Istijanto, 2006). Inferential analysis is used to test the hypothesis using simple linear regression and simple correlation, multiple linear regression and multiple correlation, followed by partial test ( $\mathrm{t}$ test), simultaneous test $(\mathrm{F}$ test), and calculation of the coefficient of determination (R2). All analyzes were performed with the SPSS program. 


\section{RESULTS AND DISCUSSION \\ Results \\ Influence of the Leadership Style of Female School Principals $\left(X_{1}\right)$ on Teacher Work Ethics (Y)}

The first hypothesis proposed in this study is that "there is an influence of the leadership style of female principals on the work ethic of teachers in SMP Negeri Samarinda". Based on the results of the simple linear regression analysis test between the principal's competence on teacher performance using SPSS, it produces a regression coefficient $\left(\mathrm{b}^{1}\right)$ of 0.752 and a constant (a) of 26.842. Furthermore, it can be seen in table 1 below:

Table 1. Results of Variable Regression Analysis of the Leadership Style ofSchool Principals

Female $\left(X_{1}\right)$ on Work Ethics $(Y)$

Coefficients $^{\text {a }}$

\begin{tabular}{|c|c|c|c|c|c|c|}
\hline \multirow[b]{2}{*}{ Model } & & \multicolumn{2}{|c|}{$\begin{array}{l}\text { Unstandardized } \\
\text { Coefficients }\end{array}$} & \multirow{2}{*}{$\begin{array}{c}\text { Standardized } \\
\text { Coefficients }\end{array}$} & \multirow[b]{2}{*}{$\mathrm{t}$} & \multirow[b]{2}{*}{ Sig. } \\
\hline & & $\mathrm{B}$ & Std. Error & & & \\
\hline 1 & (Constant) & 26,842 & 6,393 & & 4,199 & .000 \\
\hline & $\begin{array}{l}\text { Principal Leadership } \\
\text { Style }\end{array}$ & .752 & .040 & .891 & $\begin{array}{r}19,02 \\
6\end{array}$ & .000 \\
\hline
\end{tabular}

a. Dependent Variable: Teacher Work Ethic

From table 1 it can be seen that the value needed to create a regression equation between the two variables is $\mathrm{Y}=26.842+0.752 \mathrm{X} 1$. This regression equation shows the relationship between the independent variable $\mathrm{X} 1$, namely the leadership style of female school principals, and the dependent variable / dependent variable Y, namely the partially teacher work ethic. From this equation it can be concluded that the constant value of 26.842 means that if there is no change in the leadership style variable of female school principals (value $\mathrm{X} 1=0$ ), the work ethic is 26.842 and the regression coefficient value of the leadership style of female school principals is 0.752 , this shows the variable of leadership style. Female school principals have a significant positive contribution to the work ethic of teachers at State Junior High Schools in Samarinda, which means that a good leadership style for female principals will further improve the work ethic of teachers at Public SMP in Samarinda. The results of the $t$ test are useful for testing the significance of the regression coefficient (b2), whether or not the school organizational culture has a significant effect on the work ethic of the teacher. Based on the SPSS output t test results in this study as shown in table 1 , the value of $t_{\text {hit }}=4.119>t_{\text {tab }}=1.661$ or a significant value $=0.000<0.05$ then $\mathrm{H}_{1}$ is accepted, meaning that there is a significant influence on the leadership style of female school principals. towards the work ethic of SMP Negeri Samarinda teachers. 
Table 2.Significance Test of Variable Regression in the Leadership Style of Female School Principals $\left(X_{1}\right)$ on Teacher Work Ethics $(Y)$

\begin{tabular}{|c|c|c|c|c|c|c|}
\hline \multicolumn{7}{|c|}{ ANOVA $^{a}$} \\
\hline & Model & $\begin{array}{c}\text { Sum of } \\
\text { Squares }\end{array}$ & $\mathrm{df}$ & Mean Square & $\mathrm{F}$ & Sig. \\
\hline \multirow[t]{3}{*}{1} & Regression & 8811,945 & 1 & 8811,945 & 361,996 & $.000^{\mathrm{b}}$ \\
\hline & Residual & 2288,211 & 94 & 24,343 & & \\
\hline & Total 11 & 100,156 & 95 & & & \\
\hline & dent Variable & r Work Ethic & & & & \\
\hline
\end{tabular}

Seeing from table 2 comparing the significance value with the probability value, the sig value $0.000<0.05$ means that the variable $\mathrm{X}_{1}$, the leadership style of female school principals has an effect on the Y work ethic of teachers and the price of $\mathrm{F}_{\text {hit }}=361,996>\mathrm{F}_{\text {table }}=3.09$ at the 0.05 level, with a significance value of 0.000 . Thus the $\mathrm{Y}$ regression on $\mathrm{X}_{1}$ is concluded as "significant / meaningful", then the regression model can be used to predict the effect of the leadership style of female school principals on the work ethic of teachers.

The results of the data analysis on the level of closeness of the relationship between the principal's leadership style $\left(\mathrm{X}_{1}\right)$ and the work ethic of the teacher $(\mathrm{Y})$ are shown in the following:

tableTable3.Test of the Correlation Coefficient and the Coefficient of Determination between the Principal's Leadership Style $\left(X_{1}\right)$ and Work Ethic Teacher

(Y)

\begin{tabular}{ccccc}
\hline \multicolumn{4}{c}{ Model Summary } \\
\hline Model & $\mathrm{R}$ & R Square & Adjusted R Square & $\begin{array}{c}\text { Std. Error of the } \\
\text { Estimate }\end{array}$ \\
\hline 1 & $.891^{\mathrm{a}}$ & .794 & .792 & 4,934 \\
\hline a. Predictors: (Constant), Principal's Leadership Style & & \\
\hline
\end{tabular}

Based on table 3 the closeness of the relationship between the influence of the principal's leadership style on work ethic is shown by the correlation coefficient $\left(\mathrm{r}_{\mathrm{hit}}\right)$ of $0.891>\mathrm{rtab}(0.1671)$, indicating the influence of the principal's leadership style has a relationship strong teacher work ethic. While the coefficient of determination $\left(\mathrm{R}^{2)}\right.$ of 0.794 means it can be concluded that the contribution of the principal's leadership style variable $\left(\mathrm{X}_{1)}\right.$ of the teachers' work ethic variable $(\mathrm{Y})$ equal to $79.4 \%$ the remaining $20.6 \%$ is the contribution of other variables.

The Influence of School Organizational Culture $\left(\mathbf{X}_{2}\right)$ on Teacher Work Ethics $(\mathbf{Y})$

The second hypothesis proposed in this study is "there is an influence of school organizational culture on the work ethic of teachers in SMP Negeri Samarinda". Based on the test results of simple linear regression analysis between school organizational 
culture toward work ethic teacher SPSS regression coefficient direction (b2) of 0,765 and a constant (a) of 44.298 More can be seen in Table 4 below:

Table 4 .. $\quad$ Regression Analysis Variable School Organizational Culture $\left(X_{2}\right)$ Against Teacher Work Ethics $(Y)$

Coefficients $^{\text {a }}$

\begin{tabular}{|c|c|c|c|c|c|c|}
\hline \multirow[b]{2}{*}{ Model } & & \multicolumn{2}{|c|}{$\begin{array}{l}\text { Unstandardized } \\
\text { Coefficients }\end{array}$} & $\begin{array}{l}\text { Standardized } \\
\text { Coefficients } \\
\end{array}$ & \multirow[b]{2}{*}{$\mathrm{t}$} & \multirow[b]{2}{*}{ Sig. } \\
\hline & & $\mathrm{B}$ & $\begin{array}{c}\text { Std. } \\
\text { Error }\end{array}$ & Beta & & \\
\hline \multirow[t]{2}{*}{1} & (Constant) & 44.298 & 13.304 & & 3.330 & .001 \\
\hline & $\begin{array}{l}\text { School Organizational } \\
\text { Culture }\end{array}$ & .765 & .098 & .628 & 7.818 & .000 \\
\hline
\end{tabular}

a. Dependent Variable: Teacher Work Ethic

From table 4. it can be seen that the value needed to create a regression equation between the two variables is $\mathrm{Y}=44.298+0.765 \mathrm{X}_{2}$. This regression equation means that every increase in one score of school organizational culture will be followed by an increase in the teacher's work ethic score of 0.765 at a constant of 44.298. A constant of 44.298 states that if there is no increase in school organizational culture, the work ethic of the teacher is 44.298. The regression coefficient of 0.765 states that each addition of one unit of the Xvariable 2 (school organizational culture) will increase the work ethic of the teacher by 0.765 .In contrast, if the Xvariable 2 (school organizational culture) decreases by one unit, the teacher's work ethic is predicted to decrease by 0.765 . The results of the $t$ test are useful for testing the significance of the regression coefficient $\left(b_{2}\right)$, whether or not the school organizational culture has a significant effect on the work ethic of the teacher. Based on the SPSS output t test results in this study as shown in table 4, the value of $t_{\text {hit }}=3,330>\mathrm{t}_{\mathrm{tab}}=1,661$ or a significant value $=0,000<0.05$ then $\mathrm{H}_{1}$ is accepted, meaning that there is a significant influence of school organizational culture on ethos. the work of a teacher at State Junior High School in Samarinda.

Furthermore, to determine the degree of significance, the F test was carried out, the results of which can be seen in table 4 below:

Table 5. Significance Test of Regression Variables of School Organizational Culture on Teacher Work Ethics

\begin{tabular}{|c|c|c|c|c|c|c|}
\hline \multicolumn{7}{|c|}{ ANOVA $^{a}$} \\
\hline & & $\begin{array}{l}\text { Sum of } \\
\text { Squares }\end{array}$ & $\mathrm{df}$ & Mean Square & $\mathrm{F}$ & Sig. \\
\hline \multirow[t]{3}{*}{1} & Regression & 4373,916 & 1 & 4373,916 & 61,126 & $.000^{\mathrm{b}}$ \\
\hline & Residual & 6726,241 & 94 & 71,556 & & \\
\hline & Total 11 & 100,156 & 95 & & & \\
\hline
\end{tabular}

a. Dependent Variable: Teacher Work Ethic

b. Predictors: (Constant), School Organizational Culture 
Based on table 5, the price of $\left.F_{h i t}=61.126\right\rangle_{\mathrm{F} \text { table }}=3.09$ with a significance value of $0.000<0.05$. Thus the $\mathrm{Y}$ regression on $\mathrm{X}_{2}$ is concluded as "meaningful", then the regression model can be used to predict the effect of school organizational culture on teacher work ethics. The results of data analysis on the level of closeness of the relationship between school organizational culture $\left(\mathrm{X}_{2}\right)$ and teacher work ethic $(\mathrm{Y})$ are shown in table 6 below:

Table 6. Test of Correlation Coefficients and Coefficient of Determination between School Organizational Culture $\left(X_{2}\right)$ and Teacher Work Ethics $(Y)$

Model Summary

\begin{tabular}{llcrl}
\hline & & & \\
Model & $\mathrm{R}$ & R Square & Adjusted R Square & $\begin{array}{c}\text { Std. Error of the } \\
\text { Estimate }\end{array}$ \\
\hline 1 & $.628^{\mathrm{a}}$ & .394 & .388 & 8459 \\
\hline a. Predictors: (Constant), School Organizational Culture & &
\end{tabular}

Based on table 6 the closeness of the relationship between school organizational culture and teacher work ethic is shown by the correlation coefficient $\left(r_{h i t}\right)$ of $0.628>r_{\text {tab }}$ (0.1671), indicating that school organizational culture has a strong relationship with teacher work ethic. While the coefficient of determination $\left(\mathrm{R}^{2)}\right.$ of 0.394 means it can be concluded that the contribution ofvariablesschool organizational culture $\left(\mathrm{X}_{2}\right)$ to variable work ethic teacher of $39.4 \%$ remaining $60.6 \%$ is the contribution of other variables ..

\section{Influence of Principal Leadership Styles of Women $\left(X_{1}\right)$ and Organizational Culture $\left(X_{2}\right)$ together on the Work Ethic of Teachers (Y)}

The third hypothesis proposed in this study is "there is an influence of the leadership style of the principal and the culture of the school organization on the work ethic of the teachers of SMP Negeri in Samarinda" . Based on the results of the multiple linear regression analysis test between the leadership style of female school principals and culture on teacher performance using SPSS, it produces a coefficient of $\mathrm{X}_{1}\left(\mathrm{~b}_{1}\right)$ of 0.663 and a coefficient of $X_{2}\left(b_{2}\right)$ of 0.231 and a constant (a) of 9.937. A constant of 9.937 states that if there is no improvement in the leadership style of female school principals and school organizational culture, then the work ethic of the teacher is 9.937. The multiple linear regression equation is: $\mathrm{Y}=9.937+0.663 \mathrm{X}_{1}+0.231 \mathrm{X}_{2}$. Furthermore, it can be seen in table 7 below: 
Table 7. Results of Variable Regression Analysis of the Leadership Style ofSchool Principals

Female $\left(X_{1}\right)$ and School Organizational Culture $\left(X_{2}\right)$ on Teacher Work Ethics $(Y)$

\begin{tabular}{|c|c|c|c|c|c|c|}
\hline \multicolumn{7}{|c|}{ Coefficients $^{\mathrm{a}}$} \\
\hline \multirow[b]{2}{*}{ Model } & & \multicolumn{2}{|c|}{ Unstandardized Coefficients } & \multirow{2}{*}{$\begin{array}{c}\begin{array}{c}\text { Standardized } \\
\text { Coefficients }\end{array} \\
\text { Beta }\end{array}$} & \multirow[b]{2}{*}{$\mathrm{t}$} & \multirow[b]{2}{*}{ Sig. } \\
\hline & & $\mathrm{B}$ & Std. Error & & & \\
\hline & (Constant) & 9,937 & 7,682 & & $\begin{array}{r}1,29 \\
4\end{array}$ & .199 \\
\hline & Principal Leadership Style & .663 & .045 & .785 & $\begin{array}{r}14,7 \\
47\end{array}$ & .000 \\
\hline & Organizational Culture & .231 & .065 & .189 & $\begin{array}{r}3,55 \\
2\end{array}$ & .001 \\
\hline
\end{tabular}

a. Dependent Variable: Teacher Work Ethic

Hypothesis testing which states that there is a simultaneous influence on the leadership style of female school principals and organizational culture on teacher work ethics can be seen from the results of the F test (table 7). The test criteria if the significance value $<0.05$, it can be concluded that there is a significant (significant) effect.

Table 8. Significance Test of Variable Regression forPrincipal Leadership Style Female $\left(X_{1}\right)$ and School Organizational Culture $\left(X_{2}\right)$ on Teacher Work Ethics $(Y)$

\begin{tabular}{llrrrrr}
\multicolumn{7}{c}{ ANOVA $^{\text {a }}$} \\
Model & & \multicolumn{1}{c}{ Sum of } & & & \\
Squares & df & Mean Square & \multicolumn{1}{c}{ F } & Sig. \\
\hline 1 & Regression & 9085,334 & 2 & 4542,667 & 209,680 & $.000^{\mathrm{b}}$ \\
& Residual & 2014,823 & 93 & 21,665 & & \\
& Total 11 & 100,156 & 95 & & & \\
\hline
\end{tabular}

a. Dependent Variable: Teacher Work Ethic

b. Predictors: (Constant), Organizational Culture, Principal's Leadership Style

The test results obtained by $F_{\text {hit }}(209.680)>F_{\text {tab }}$ (3.09) and a significance value of $0.000<0.05$, it can be concluded that $\mathrm{H}_{0}$ is rejected and $\mathrm{H}_{1}$ is accepted, which This means that there is a simultaneous significant influence between the leadership style of female school principals and organizational culture on the work ethic of SMP Negeri Samarinda teachers. The results of data analysis on the level of closeness of the relationship between the leadership style of female school principals $\left(\mathrm{X}_{1}\right)$ and school organizational culture $\left(\mathrm{X}_{2}\right)$ on teacher work ethics $(\mathrm{Y})$ are shown in table 9 below: 
Table 9.Test Test Correlation Coefficient andDetermination Coefficient of VariableLeadership Style Female School Principals $\left(X_{1}\right)$ and School Organizational Culture $\left(X_{2}\right)$ on Teacher Work Ethics $(Y)$

Model Summary

\begin{tabular}{lcccc}
\hline & & & & \multicolumn{2}{c}{ Std. Error of the } \\
Model & $\mathrm{R}$ & R Square & Adjusted R Square & \multicolumn{2}{c}{ Estimate } \\
\hline 1 & $.905^{\mathrm{a}}$ & .818 & .815 & 4,655 \\
\hline a. Predictors: (Constant), Organizational Culture, Principal Leadership Style
\end{tabular}

Based on table 9 the closeness of the relationship between the leadership style of female school principals $\left(\mathrm{X}_{1}\right)$ and school organizational culture $\left(\mathrm{X}_{2}\right)$ on teacher work ethic $(\mathrm{Y})$ is shown by the correlation coefficient $\left(\mathrm{r}_{\mathrm{hit}}\right)$ ) of $0.905>\mathrm{r}_{\text {tab }}(0.1689)$. While the coefficient of determination $\left(\mathrm{R}^{2}\right.$ of 0.818 means including having a strong relationship and it can be concluded that the contribution of the principal's leadership style variable female $\left(\mathrm{X}_{1}\right)$ and organizational culture of schools $\left(\mathrm{X}_{2}\right)$ of the work ethic of teachers $(\mathrm{Y})$ $81.8 \%$ the remaining $18.2 \%$ is the contribution of other variables outside of these variables.

\section{DISCUSSION}

Based on the results of the data analysis above, it is clear that of the three research hypotheses tested, it turns out that the three hypotheses have a significant effect. Both individually and simultaneously the variables of the leadership style of female principals and school organizational culture have a significant influence on the work ethic of teachers. Furthermore, the discussion of the results of this study will discuss several things, namely the results of hypothesis testing for each variable, and the results of the analysis of the theories stated earlier.

\section{The Influence of the Leadership Style of the Female School Principal $\left(X_{1}\right)$ on the Work Ethic of Teachers (Y)}

Based on the results of the simple regression analysis of $\mathrm{X}_{1}$ on $\mathrm{Y}$, it is obtained a greater significance value and $\alpha$ value, and the regression coefficient $\left(b_{1}\right)>0$, means that the hypothesis that there is The significant influence of the leadership style of female school principals on the work ethic of SMP Negeri Samarinda teachers is accepted. Furthermore, the closeness of the relationship between the leadership style of female school principals and the work ethic of teachers is shown by the correlation coefficient (r) of 0.891 which indicates a relationship between the leadership style of female principals and the work ethic of teachers. While the coefficient of determination $\left(\mathrm{R}^{2)}\right.$ amounted to 0,794 , which means donations principal's leadership style female $\left(\mathrm{X}_{1)}\right)^{\text {to }}$ the work ethic of teachers (Y) amounted to $79.4 \%$, the remaining $20.6 \%$ influenced by other factors not examined, as : teacher motivation, work environment, and others. There is a positive and significant influence between the leadership style of female school principals on the work ethic of teachers as revealed in this study. This research also supports the results of research that has been done before, namely (PujiHastuti, AT Soegito, 2009), a study entitled The Effect of Principal's Participatory Leadership Style and School Climate on the Work Ethic of State Junior High School Teachers in Sub 
District 02 Semarang City. The results showed that there was a positive and significant influence of the principal's participatory leadership style on the work ethic of the SMP Negeri teachers in Sub District 02 Semarang City. This leadership style is in accordance with the opinions of several experts, including according to (Nurkolis, 2006), leadership style is a behavior pattern that is preferred by a leader in the process of directing and influencing workers. According to (Thoha, 2013), leadership style is a behavior norm used by a person when that person influences others. In addition, according to (Veithzal, 2002), leadership is a comprehensive pattern of a leader's actions, both visible and invisible to his subordinates. Meanwhile, according to (Hadari, 2006), it defines that leadership style is a pattern of behavior shown by a person when he tries to influence others. Meanwhile, according to Hadari Nawawi's opinion, leadership style is defined as the behavior or method the leader chooses and uses in influencing the thoughts, feelings, attitudes and behavior of members of the organization or their subordinates. The results of research conducted by Mukh et al and McCrea \&Ehrich (Surya, 2010), state that the peculiarities of the leadership of female school principals consist of sensitive leading, people resourcing, and active managing, the description is as follows.

Sensitive leading recognizes the dynamic role of all stakeholders in an organization, allowing others to contribute through delegation. Examples of the application of leadership that is more responsive and is a feminine approach include: (a) shaping the arrangement into a comfortable way of life rather than just a workplace, (b) seeing other people (both educators and students) as all citizens in their own right who have needs, feelings and ideas, (c) showing genuine interest and concern for others, (d) encouraging students to express opinions and ideas related to school programs.

People resourcing or empowering people, the female principal strongly encourages all stakeholders to participate in educational arrangements, develop the potential of educators, and support a conducive work culture and climate. The implementation of people resourcing can be in the form of: (a) being sensitive to the personal challenges of educators and living conditions, (b) encouraging women and people from minority groups to try new responsibilities and achieve promotions, (c) providing internship opportunities for women and people from minority groups, helping them by developing skills and experiences needed as promotional capital for higher career paths, (d) actively involved in teachers' associations that discuss teaching and practical learning, (e) working in teams in a mutually supportive relationship in a professional manner, (f) providing professional development opportunities for staff, parents and the wider community, $(\mathrm{g})$ building a supervisory process while maintaining support for staff. Active managing or actively managing is doing educational planning, organizing and monitoring as an ongoing process. Female school principals tend to build trust with staff, regulate the roles and responsibilities of educators with teaching as their main focus, provide opportunities for teachers to cooperate and learn from each other, and institutionalize educational monitoring in the form of accountability that includes students, teachers, leaders, management, and system. The implementation of active managing includes planning, organizing, and monitoring, with the characteristics of responsive planning, sensible organizing, and accountable monitoring. As a leader, the principal must be able to create changes effectively in the appearance of the group. A leader must be able to move other people so that they voluntarily do what a leader wants. Therefore the principal must know the function of his leadership. The leadership style of 
a good female principal is very influential in improving the work ethic of the teacher. The principal as a leader as well as a supervisor in providing direction and guidance must run actively so that mistakes can be resolved as early as possible. This will encourage teachers to carry out their tasks in a better direction. The acceptance of the hypothesis that there is a significant influence of the leadership style of female school principals on the work ethic of SMP Negeri Samarinda teachers shows that the better the leadership style of female principals, the better the work ethic of the teachers will be. Given the size of the contribution and the importance of the leadership style of female school principals to the work ethic of teachers, a leader in schools, namely the principal, should be able to determine attitudes in implementing his leadership style in schools to improve the work ethic of teachers.

\section{The Influence of School Organizational Culture $\left(\mathbf{X}_{2}\right)$ on Teacher Work Ethics $(\mathbf{Y})$}

Based on the results of the simple regression analysis of $\mathrm{X}_{2}$ on $\mathrm{Y}$, the significance value is greater and the value of $\alpha$, and the regression coefficient $\left(b_{1}\right)>0$, means that the hypothesis that there is a significant influence the culture of the school organization on the work ethic of SMP Negeri Samarinda teachers was accepted. Furthermore, the closeness of the relationship between school organizational culture and teacher work ethic is shown by the correlation coefficient ( $\mathrm{r}$ ) of 0.628 which indicates a relationship between school organizational culture and teacher work ethics. While the coefficient of determination $\left(\mathrm{R}^{2)}\right.$ of 0.394 , which means donations principal's leadership style female $\left(\mathrm{X}_{2}\right)$ of the work ethic of teachers $(\mathrm{Y})$ amounted to $39.4 \%$, the remaining $60.6 \%$ is influenced by other factors not examined, as : teacher motivation, work environment, and others. There is a positive and significant influence between the culture of the school organization on the work ethic of teachers as revealed in this study. This research also supports the results of previous research, namely (Fahrudin, 2020), entitled the influence of organizational behavior and culture on the work ethic of State Junior High School teachers in Kramatmulya District, Kuningan Regency. The results showed that: (1) There is a positive and significant influence of organizational behavior on the work ethic of teachers. (2) There is a positive and significant influence of organizational culture on work ethic. (3) There is a positive and significant influence on organizational behavior and culture together (simultaneously). In another part, Kotter and Heskett (1992) in (Molan, 2006) also explain three concepts of organizational culture, namely: (1) strong culture (2) strategically suitable culture, (3) civilized culture. Organizations that have a strong culture are characterized by the tendency for almost all managers to share a set of values and methods of running the organization's business. New employees adopt these values very quickly. A new executive can be corrected by his subordinates, as well as by his boss, if he violates organizational norms. In organizations with a strong culture employees tend to line up following the same values. Common values and behaviors make people feel comfortable at work. A sense of commitment and loyalty makes people try even harder. In a strong culture provides the structure and control needed. rather than stifling formal bureaucracies that can suppress growing motivation and innovation. Then the strategic culture fit explicitly states that the direction of the culture must harmonize and motivate members, if it is to improve organizational performance. The main concept used here is "conformity". So, a culture is considered good if it fits the context. What is meant by context can be in the form of objective conditions of the organization or its 
business strategy. Furthermore, an active existing culture departs from the logic of its subordinates that culture that can help organizations anticipate and adapt to environmental changes will be associated with superior performance over time. The process of forming a culture in the organization with the emergence of ideas or solutions which are then formed in a culture in the organization can start from anywhere, from individuals or groups, from the bottom or top levels. Cultural formation cannot be done in an instant but it takes time and even costs that are not small to be able to accept new values in the organization. It has been accepted that the hypothesis that there is a significant influence of school organizational culture on the work ethic of teachers in SMP Negeri in Samarinda, shows the better the culture school organization, the work ethic of the teacher will also be better. Given the large contribution and importance of school organizational culture to teacher work ethics, a good organizational culture will improve teacher work ethics.

\section{Leadership Style of Female School Principals $\left(X_{1}\right)$ and School Organizational Culture $\left(\mathbf{X}_{2}\right)$ on Teacher Work Ethics (Y)}

Based on the results of multiple regression analysis of $\mathrm{X}_{1}$ and $\mathrm{X}_{2}$ on $\mathrm{Y}$, the significance value is greater than the $\alpha$ value, and the regression coefficient (b12) ) $>0$, it means that the hypothesis which states that there is an influence of the leadership style of female school principals and school organizational culture on the work ethic of SMP Negeri Samarinda teachers is accepted. Furthermore, the closeness of the relationship between the leadership style of female school principals and the culture of the school organization together on the work ethic of teachers is shown by the correlation coefficient (r) of 0.905 , which indicates a strong relationship between the leadership style of female principals and the culture of the school organization together. against the work ethic of the teacher. While the coefficient of determination $\left(\mathrm{R}^{2)}\right.$ of 0.818 , which means donations principal's leadership style female $\left(\mathrm{X}_{1}\right)$ and organizational culture of schools $\left(\mathrm{X}_{2}\right)$ of the work ethic of teachers (Y) $81.8 \%$, the remaining $18,2 \%$ are affected other factors not examined, such as: teacher training, teacher welfare, teacher motivation, teacher discipline, work environment, communication climate and others. The results showed that the leadership style of female school principals and school organizational culture influenced the work ethic of teachers. The principal as a leader according to (Andang, 2014) "The principal's managerial ability plays a role in school effectiveness, because the principal must be able to manage existing resources in the school environment. In managing the school, the principal has a very big role. The principal is the driving force, determining the direction of policy towards schools and education at large. As the manager of educational unit institutions, the principal is required to always improve the effectiveness of his performance. To achieve an effective school quality, the principal and all stakeholders work together with great solidarity. Although the leadership style of female principals and organizational culture are not the only factors that affect the work ethic of teachers, the results of this study are supported by the opinion of several experts, that the leadership style of female principals and the culture of school organizations are determining factors that can promote ethos. teacher work. If the leadership style of female school principals and school organizational culture is good and very high, as a result, a good work ethic of teachers in schools will be formed. 


\section{CONCLUSION}

Based on the results of research on regression analysis and correlation and discussion by fulfilling all test data analysis requirements, namely data normality test, linearity test, multicollinearity test, heteroscedasticity test.Data variables, then tested the hypothesis, then in this study it can be concluded as follows:

1. The leadership style of female principals has an effect on the work ethic of teachers, which means that the higher or better the leadership style of female principals will result in an increase in the work ethic of teachers. The results of the simple regression test of this study show that the leadership style of female school principals has an influence of 0.794 on the work ethic of teachers so that it contributes around $79.40 \%$. So that the effect is positive. The results of the partial correlation test showed that the principal's leadership effectiveness was 0.891 so that the relationship was very strong.

2. The school organizational culture affects the work ethic of the teacher, which means that the increasing or better the school organizational culture will result in an increase in the work ethic of the teacher. The simple regression test results on organizational culture have an effect of 0.394 on teacher job satisfaction so that it contributes an influence of $39.40 \%$. So that the effect is positive. The results of the partial correlation test showed that the professional competence of teachers was 0.628 so that the relationship was strong.

3. The leadership style of female school principals and the culture of the school organization jointly influence the work ethic of teachers, which means that the increasing leadership style of female principals and the culture of school organizations will result in an increase in the work ethic of teachers. The results of multiple regression tests on the leadership style of female school principals and school organizational culture have an influence of 0.818 on the work ethic of the teacher so that it contributes to an influence of $81.80 \%$. So that the effect is positive. From the results of the correlation test, the leadership style of female school principals is 0.891 and the school organizational culture is 0.628 on the work ethic of teachers. The result of the correlation coefficient shows that what has more influence is the leadership style of female school principals which is very strong compared to the school organizational culture.

\section{ACKNOWLEDGMENTS}

With the completion of this article, the authors would like to express their deepest gratitude to: Allah SWT for the abundance of gifts and guidance, thank you very much to the supervisors and examiners, principals and teachers whose schools are places of research, as well as parents, family, as well as fellow education management master students who support in working on this article.

\section{REFERENCES}

Alwi, Hasan, \&Dkk. (2008). Big Indonesian Dictionary. Jakarta: Balai Pustaka.

Armstrong, M., \& Baron, A. (2005). Performance Management in Action. London: Institute of Personal and Development.

Torch. (2014). Principal Leadership Management. Jogjakarta: Arruzz Media.

Andriani, S., Kesumawati, N., \&Kristiawan, M. (2018). The influence of the 
transformational leadership and work motivation on teachers performance. International Journal of Scientific and Technology Research, 7(7), 19-29.

Benninga, JS (1991). Moral, Characteristic and Civic Education in Elementary School. Colombia University New York and London: Teachers College.

Bogler. (2001). The influence of Leadership Style on Teacher Job Satisfaction. 32(5), $662-683$.

Burhanuddin. (1994). Management and Leadership Administration Analysis. Jakarta: Earth Literacy.

Burn, G., \& Martin, B.. (2010). Examination of the effectiveness of male and female educational leadership styles of leadership. Journal of Invitational Theory and Practice, 16 (Annua, 30.

Bush, T., \& Coleman, M. (2000). Leadership and strategic management in education. University of Leicester: EMDU.

Darodjat, \&Achmad, T. (2015) . The Importance of High Work Culture and Strong Absoutte. Bandung: PT.RefikaAditama.

Depdiknas. (2001). School-Based Quality Improvement Management. Jakarta: Depdiknas.

Fahrudin, S. (2020). The Influence of Behavior and Organizational Culture on the Work Ethic of School Teachers Middle First Negeri. Edum Journal, 3(1), 59-71. Https://doi.org/10.31943/edumjournal.v3i1.55

Gultom, D.. (2014) The influence of corporate organizational culture and motivation on employee performance in PT. Perusahaan Gas Negara (Persero) Tbk Medan. Scientific Journal of Management and Business, 14(2), 176-184.

Hadari, N. (2006). Leadership Effectiveness of Organizations. Yogyakarta: Gajah Mada University Press.

Halilah. (2011) Women's Leadership in Educational Management Management of Education, 1(1), 1-9.

Hartani, A. (2011) . M education management. Yogyakarta: (LaksbangPressindo.

Hoffman, DM (1996). Culture and Self in Multicultural Education: Reflections on Discourse, Text, and Practice. Journal, American Educational Research, 33(3), 545-569. Https: // doi. org / 10.3102\% 2F00028312033003545

Respect, T. (2016). The Influence of Organizational Culture, Job Rotation on Work Motivation and Employee Performance. Journal of EMBA, 4(2), 298-31-.

Kartini, K. (2005). Leaders and Leadership What is Abnormal Leadership? Jakarta: Raja GrafindoPersada.

Luthans, F. (2006). Organizational Behavior. Singapore: McGraw-Hill.

Mangkunegara, AP (2005). Behavior and Organizational Culture. Bandung: PT. RafikaAditama.

Molan, B (2006). Corporate Culture and Performance, translation of the Impact of Corporate Culture on Performance. Jakarta: PT. Prehalindo.

Mondy, R., Sharplin, Arthur, Premeux, \& Shane, R. (2005). Management, Concepts, Practices, and Skills (Fifth ed). Massachusetts: Silmon\& Schuster Inc.

Muliyana, R. (2004). Articulating Educational Values. Bands ung: Alfabeta.

Mulyadi, A. (2008). Islam and Work Ethics: The Relationship Between Religious Quality and Work Productivity Ethos in the Industrial Area of Bekasi Regency. Turats, 4(1), $1-19$. 
Nurcholis. (2006). School Based Management. Jakarta: Grasindo.

Prihayanto, Susandi. \&Ratnawati, I. (2011). The Influence of Organizational Culture and Motivation on Employee Performance. SusandiPrihayanto's Thesis Journal.

PujiHastuti, AT Soegito, FR (2009). The Influence of Principal's Participatory Leadership Style and School Ikloim on the Work Ethic of State Junior High School Teachers in Sub District 02 Semarang City. 31-46.

Purwanti, K., Murniati, ARY (2014). Leadership of the Principal in Improving Teacher Competence at SMP Negeri 2 East Simeulue. Scientific Journal of Didactics, $X I V(2), 390-400$.

Purwanto, N. (2009). Education Administration and Supervision. PT RemajaRoosdakarya.

Robbins, SP (nd). Organizational Behavior: Concept Controversies, Application. New Jersey: Englewood Cliff.

Santoso, \&Jalu, E. (2012). Good ethos; 7 Best and Noble Work Ethics. Jakarta: PT. Elex Media Komputindo.

Sinamo, J. (2008). 8 Your Navigator's Professional Work Ethic Towards Success. Jakarta: DarmaMahardika Institute.

Surya, P. (2010). Women's Leadership Has Delay in the Field of Education. Journal of Educational Management, 6(2).

Suryo, BD (2010). The Influence of Transformational Leadership Style, Organizational Culture and Innovation on Performance (Studies at Orphanages in Tomohon City and Minahasa District). Journal of Management Applications, 8(2). https://jurnaljam.ub.ac.id/index.php/jam/article/view/337

Syaiful, S. (2009). Professional Capabilities of Teachers and Education Personnel. Medan: Alfabeta.

Tasmara, T. (2002). Cultivate an Islamic Work Ethic. Jakarta: Echo of Human.

Tebba, S. (2003). Building a Work Ethic in Tsawuf's Perspective. Bandung: Pustaka Nusantara.

Thoha, M. (2013). Leadership in Management, 1st edition. Jakarta: PT. Raja GrafindoPersada.

Tohidi, H., \& Jabbari, MM (2012). Organizational culture and leadership. Procedia Social and Behavioral Sciences, 31, 856-860. https://doi.org/10.1016/j.sbspro.2011.12.156

Veithzal, R. (2002). Leadership and Organizational Behavior. Jakarta: Raja GrafindoPersada. 